\title{
Oncogenic microRNA-142-3p is associated with cellular migration, proliferation and apoptosis in renal cell carcinoma
}

\author{
YIFAN LI ${ }^{1-3^{*}}$, DUQUN CHEN ${ }^{1-3 *}$, LU JIN $^{1-3}$, JIAJU LIU $^{1,2,4}$, YUCHI LI $^{2,4}$, ZHENGMING SU $^{1,2,4}$, \\ ZHENGYU QI ${ }^{2}$, MIN SHI $^{2}$, ZHIMAO JIANG ${ }^{2}$, SHANGQI YANG ${ }^{1,2}$, YAOTING GUI $^{2}$, \\ XIANGMING MAO ${ }^{1,2}$, XIONGHUI WU ${ }^{1,2}$ and YONGQING LAI ${ }^{1,2}$ \\ ${ }^{1}$ Department of Urology, Peking University Shenzhen Hospital; \\ ${ }^{2}$ The Guangdong and Shenzhen Key Laboratory of Male Reproductive Medicine and Genetics, Institute of Urology, \\ Peking University Shenzhen Hospital, Shenzhen PKU-HKUST Medical Center, Shenzhen, Guangdong 518036; \\ ${ }^{3}$ Department of Urology, Anhui Medical University, Anhui, Hefei 230032; ${ }^{4}$ Department of Urology, \\ Shantou University Medical College, Shantou, Guangdong 515041, P.R. China
}

Received February 2, 2015; Accepted October 23, 2015

DOI: $10.3892 / \mathrm{ol} .2015 .4021$

\begin{abstract}
MicroRNAs (miRNAs/miRs) serve an important role in the regulation of carcinogenic pathways. RCC is the most prevalent kidney cancer that occurs in adults. miRNAs have gained increasing attention due to their association with RCC tumorigenesis, serving as biomarkers for early detection and progression monitoring, and as potential targets for molecular therapy. Upregulation of miRNA-142-3p has been previously identified in RCC tissues by microarray profile, however, its expression and function in RCC have not yet been validated. In the present study, quantitative polymerase chain reaction was performed to quantify the relative expression of miR-142-3p in 53 paired RCC and adjacent normal tissues. Furthermore, wound healing, 3-(4,5-dimethylthiazol-2-yl)-2,5-diphenyltetrazolium bromide and flow cytometry assays were performed to analyze the impacts of miR-142-3p on cellular migration, proliferation and apoptosis. The results demonstrated that miR-142-3p was significantly upregulated in RCC tissues compared with adjacent normal tissues. Downregulation of miR-142-3p, induced by chemically synthesized miR-142-3p inhibitor, significantly suppressed cell migration and proliferation, and promoted cell apoptosis in 786-O and ACHN cells, supporting the theory
\end{abstract}

Correspondence to: Dr Yongqing Lai or Dr Xionghui Wu, Department of Urology, Peking University Shenzhen Hospital, Institute of Urology, Shenzhen PKU-HKUST Medical Center, 1120 Lianhua Road, Shenzhen, Guangdong 518036, P.R. China

E-mail: yqlord@163.com

E-mail: 13802260619@163.com

*Contributed equally

Key words: microRNA, microRNA-142-3p, renal cell carcinoma, oncogene that miR-142-3p may function as an oncogene in RCC. The potential clinical significance of miR-142-3p, as a biomarker and therapeutic target, provides rationale for further investigation into the miR-142-3p-mediated molecular pathway and how it is associated with RCC development.

\section{Introduction}

MicroRNAs (miRNAs/miRs) are 22 -nt, single-stranded, non-coding RNAs that serve an important role in regulating carcinogenic pathways $(1,2)$. miRNAs may lead to messenger RNA (mRNA) degradation or translational repression by binding to the 3 '-untranslated regions of target genes, and are involved in a wide range of biological and pathological processes, including cell differentiation, migration, growth, proliferation, apoptosis and metabolism (3-6). miRNA expression is often dysregulated in various types of cancer, with either an oncogenic function when overexpressed or a tumor suppressor function when downregulated $(2,7,8)$. Whether miRNA functions as an oncogene or tumor suppressor gene is primarily dependent on the regulation of its target genes. Due to the presence of complementarity between miRNAs and target gene mRNAs, each miRNA may regulate multiple mRNAs and each mRNA may be targeted by multiple miRNAs (7). miRNAs exert their function in a temporal- and tissue-specific manner (8). In clinical practice, miRNAs may prove invaluable, being exploited as biomarkers for diagnostic, prognostic and monitoring purposes. Additionally, miRNAs may serve as possible targets for novel therapeutic approaches, particularly in patients with tumor subtypes that do not respond to therapies presently available (1).

Kidney cancer is the 14th most prevalent cancer in the world, with incidence and mortality rates that have recently plateaued in Europe and North America, but continue to increase in developing countries $(9,10)$. Renal cell carcinoma (RCC) is the most frequent kidney cancer that develops in adults, accounting for $290 \%$ of all renal tumors and 3.9\% of all cancers $(11,12)$. The three most prevalent histological 
subtypes of RCC include clear cell RCC (ccRCC), papillary RCC and chromophobe RCC, with a prevalence of 70, 10 and $5 \%$, respectively (13). RCCs are clinically silent at their earliest stages, therefore, at the time of the initial diagnosis, up to $30 \%$ of patients have already progressed to a locally advanced disease state or exhibit metastases (14). If detected promptly, early-stage RCC is curable in $>90 \%$ of cases (15). In $20-40 \%$ of patients, a recurring disease will develop following surgical nephrectomy due to the lack of effective adjuvant therapy, including chemotherapy or radiotherapy (16).

Therefore, miRNAs have gained increasing attention as important factors associated with RCC tumorigenesis and development, serving as biomarkers for early detection and progression monitoring, and as potential targets for molecular therapy $(16,17)$. However, to the best of our knowledge, the expression and function of miR-142-3p in $\mathrm{RCC}$ has not yet been fully investigated. Previous microarray chip studies have demonstrated that miR-142-3p is overexpressed in RCC tissues compared with adjacent normal or benign kidney tissues (18-21). It has also been reported that miR-142-3p is dysregulated in malignancies of the breast (22), thyroid (23), liver (24), stomach (25), lung (26), blood (27,28), colorectum (29), testes (30), esophagus (31), head and neck (32), and bone (33). The present study establishes the oncogenic role of miR-142-3p in RCC, demonstrating how it regulates cell migration, proliferation and apoptosis.

\section{Materials and methods}

Cell culture and transfection. Human RCC cells (786-O and ACHN) and normal human embryo kidney cells (293T) from the Guangdong and Shenzhen Key Laboratory of Male Reproductive Medicine and Genetics (Shenzhen, China) were seeded and grown in Dulbecco's modified Eagle's medium (DMEM) (Gibco; Thermo Fisher Scientific, Inc., Waltham, MA, USA) with $10 \%$ fetal bovine serum, and $1 \%$ glutamine and included $100 \mu \mathrm{g} / \mathrm{ml}$ penicillin and $100 \mathrm{mg} / \mathrm{ml}$ streptomycin sulfates (Invitrogen; Thermo Fisher Scientific, Inc.) at $37^{\circ} \mathrm{C}$, in a humidified atmosphere containing $5 \% \mathrm{CO}_{2}$. For the downregulation of miR-142-3p, synthesized miR-142-3p inhibitor (Shanghai GenePharma, Co., Ltd., Shanghai, China) was transfected into cells using Lipofectamine ${ }^{\circledR} 2000$ (Invitrogen; Thermo Fisher Scientific, Inc.), and then the cells were mixed in the Opti-MEM ${ }^{\circledR}$ I Reduced Serum Medium (Gibco; Thermo Fisher Scientific, Inc.) $24 \mathrm{~h}$ after plating. Quantitative polymerase chain reaction (qPCR) was used to verify the efficiency of transfection. The sequence of the miR-142-3p inhibitor was 5'-UCC AUA AAG UAG GAA ACA CUA CA-3' and the negative control was 5'-CAG UAC UUU UGU GUA GUA CAA-3'.

Human patient samples. A total of 53 paired RCC tissues and adjacent non-cancerous kidney tissues were collected from patients in the Peking University Shenzhen Hospital (Shenzhen, China), from September 2012 to November 2014. Written informed consent was provided by all patients. Histological and pathological diagnostics for patients with RCC were determined according to the 2009 American Joint Committee on Cancer staging system (34). The patients with RCC had not been treated with either chemotherapy or radiotherapy prior to tissue sampling. Tissue samples were snap-frozen and stored
Table I. Clinicopathological features observed in renal cell carcinoma patients.

\begin{tabular}{lc}
\hline Characteristic & Value \\
\hline Mean age (range), years & $49(27-71)$ \\
Gender, $\mathrm{n}$ & \\
Male & 35 \\
Female & 18 \\
Histological type, $\mathrm{n}$ & \\
Clear cell & 42 \\
Papillary & 11 \\
pT-stage, $\mathrm{n}$ & \\
T1 & 30 \\
T2 & 20 \\
T3+T4 & 3 \\
Fuhrman grade, $\mathrm{n}$ & \\
I & 18 \\
II & 23 \\
III & 9 \\
IV & 3 \\
AJCC clinical stage, $\mathrm{n}$ & \\
I & 31 \\
II & 19 \\
III+IV & 3 \\
\hline
\end{tabular}

pT, primary tumor; AJCC, American Joint Committee on Cancer.

in a cryo freezer at $-80^{\circ} \mathrm{C}$ in RNAlater ${ }^{\circledR}$ RNA Stabilization Agent (Qiagen, Inc., Valencia, CA, USA) for further research. The clinicopathological information of all the patients is presented in Table I.

RNA isolation, $c D N A$ synthesis and $q P C R$. Total RNA was extracted from the cell lines and tissues using TRIzol ${ }^{\circledR}$ Reagent (Invitrogen; Thermo Fisher Scientific, Inc.), and was purified using the RNeasy ${ }^{\circledR}$ Maxi kit (Qiagen, Inc.) according to the manufacturer's protocols. The amount of RNA was measured on a NanoDrop 2000c (Thermo Fisher Scientific, Inc.) and the RNA samples with 260/280 ratios of 1.8-2.0 were utilized for further experiments. Synthesis of cDNA with reverse transcriptase was performed with the miScript II RT kit (Qiagen, Inc.). The sequence of the forward primer for miR-142-3p was 5'-TGT AGT GTT TCC TAC TTT ATG GA-3' and the reverse primer was provided by the miScript SYBR ${ }^{\circledR}$ Green PCR kit (Qiagen, Inc.). qPCR analysis was performed using the same kit, according to the manufacturer's protocols, on the LightCycler $^{\circledR} 480$ Real-Time PCR system (Roche Diagnostics, Basel, Switzerland). The thermal cycling conditions for PCR were as follows: $95^{\circ} \mathrm{C}$ for $15 \mathrm{~min}$, followed by 40 cycles of $94^{\circ} \mathrm{C}$ for $15 \mathrm{sec}, 55^{\circ} \mathrm{C}$ for $30 \mathrm{sec}$ and $72^{\circ} \mathrm{C}$ for $30 \mathrm{sec}$. Quantification cycle $(\mathrm{Cq})$ values of miR-142-3p were equilibrated to U6, which was used as an internal control. The forward primer of U6 was 5'-CTC GCT TCG GCA GCA CA-3' and the reverse primer was 5'-ACG CTT CAC GAA TTT GCG T-3'. Relative expression was calculated using the $\Delta \Delta \mathrm{Cq}$ method. 
A

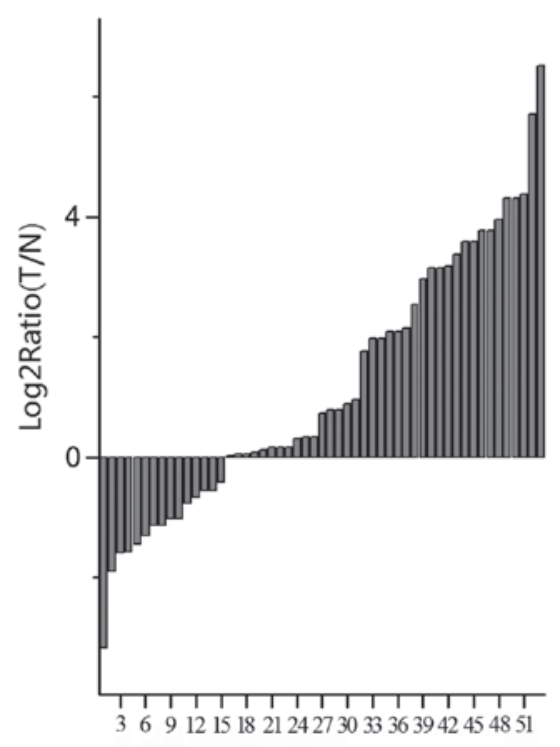

B

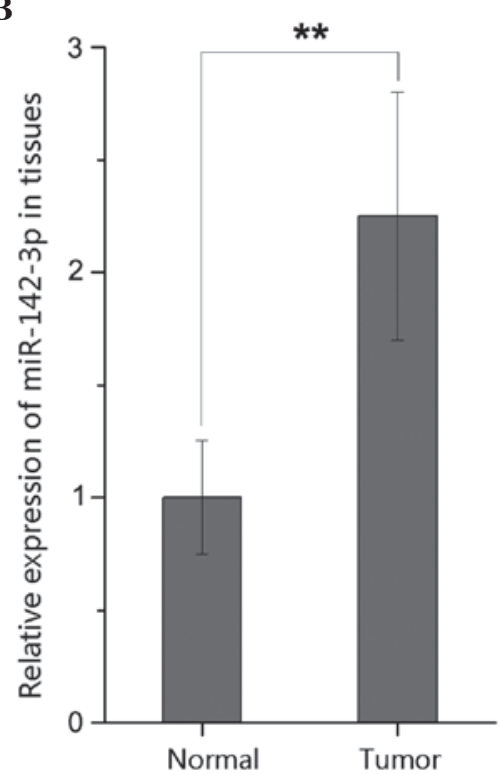

Figure 1. Expression of miR-142-3p in 53 paired RCC and adjacent normal tissues. (A) Log2 ratios of miR-142-3p expression in 53 paired RCC tumor (T) tissues to normal (N) kidney tissues. (B) Relative expression of miR-142-3p in normal and RCC tissues. miR, microRNA; RCC, renal cell carcinoma. ${ }^{* *} \mathrm{P}<0.01$.

Wound healing assay. A wound scratch assay was performed to evaluate the migratory ability of the 786-O and ACHN cells in vitro. A total of $\sim 3 \times 10^{5}$ cells were seeded into each well within a 12-well dish, and each was transfected with either 100 pmol of chemically synthesized miR-142-3p inhibitor or a negative control, using Lipofectamine 2000. Following $6 \mathrm{~h}$ of transfection, a sterile $200-\mu 1$ pipette tip was used to scratch a clear line through the cell layer. The cells were then rinsed with phosphate-buffered saline (PBS) and cultured in serum-free DMEM at $37^{\circ} \mathrm{C}$ in a humidified chamber, containing $5 \%$ $\mathrm{CO}_{2}$. Using a digital camera system, images were captured at 0,24 and $48 \mathrm{~h}$ after the scratches were made. The experiments were performed in triplicate and repeated $\geq 3$ times.

Cell proliferation assay using 3-(4,5-dimethylthiazol-2-yl)-2,5-diphenyltetrazolium bromide (MTT). MTT assays were conducted to analyze the proliferation ability of the $786-\mathrm{O}$ or ACHN cells. A total of $\sim 5 \times 10^{3} 786-\mathrm{O}$ or ACHN cells were seeded into each well within 96-well plates, with 5 replicate wells of each condition. Each well was transfected with either 5 pmol miR-142-3p inhibitor, or a negative control, and proliferation was measured at $0,24,48$ or $72 \mathrm{~h}$ post-transfection. Prior to measurement, $20 \mu 1 \mathrm{MTT}(5 \mathrm{mg} / \mathrm{ml}$; Sigma-Aldrich, St. Louis, MO, USA) was added to each well, with the 96 -well plates then incubated at $37^{\circ} \mathrm{C}$ in a humidified chamber, containing $5 \% \mathrm{CO}_{2}$, for $6 \mathrm{~h}$. Subsequently, the MTT medium mixtures were discarded and $120 \mu \mathrm{l}$ dimethylsulfoxide (Sigma-Aldrich, Shanghai, China) was added. Following agitation for $30 \mathrm{~min}$ at room temperature, the optical density values were measured by the iMark Microplate Absorbance Reader (Bio-Rad Laboratories, Inc., Hercules, CA, USA) at a wave length of $490 \mathrm{~nm}$, with $630 \mathrm{~nm}$ serving as the reference wave length.

Flow cytometry assay. The Coulter ${ }^{\circledR}$ Epics XL ${ }^{\circledR}$ flow cytometer (Beckman Coulter, Inc., Brea, CA, USA) was used to quantify the early apoptosis rate of the 786-O and ACHN cells, with Annexin V-fluorescein isothiocyanate (FITC) and propidium iodide (PI) staining (Invitrogen; Thermo Fisher Scientific, Inc.). A total of $\sim 3 \times 10^{5} 786-\mathrm{O}$ or ACHN cells were seeded into 6-well plates for the cell apoptosis assay. The cells were transfected with 200 pmol miR-142-3p inhibitor, or the negative control, for $6 \mathrm{~h}$. Following a 48-h transfection, the cells, including floating cells, were harvested, washed twice with $4^{\circ} \mathrm{C}$ PBS and resuspended in $100 \mu 11 \mathrm{X}$ binding buffer at a concentration of at least $3 \times 10^{6}$ cells $/ \mathrm{ml}$. This suspension (100 $\mu \mathrm{l}$ ) was stained with $5 \mu \mathrm{l}$ Annexin V-FITC and $5 \mu \mathrm{l}$ PI for $15 \mathrm{~min}$ at room temperature in the dark. Following the addition of $400 \mu \mathrm{l}$ binding buffer to each tube, the cells were analyzed by flow cytometry. Each experiment was performed at least 3 times.

Statistical analysis. For the comparison of miR-142-3p expression levels in matched tumor and normal samples, a paired $\mathrm{t}$-test was performed. The relative expression of miR-142-3p in tissues was presented as the mean \pm standard error. All other data were presented as the mean \pm standard deviation from the three independent experiments. Statistical analysis was performed using SPSS software, version 19.0 (IBM SPSS, Armonk, NY, USA). Statistical significance was determined with Student's t-test. $\mathrm{P}<0.05$ was considered to indicate a statistically significant difference.

\section{Results}

miR-142-3p is upregulated in RCC tissues compared with adjacent normal tissues. A total of 53 paired RCC and adjacent normal tissues were analyzed using qPCR in order to quantify the expression pattern of miR-142-3p in each tissue type. The results demonstrated that the expression of miR-142-3p $[\log 2(\mathrm{~T} / \mathrm{N})]$ was generally increased $(38 / 53)$ in the tumors in comparison with the paired normal samples (Fig. 1A). The 
A

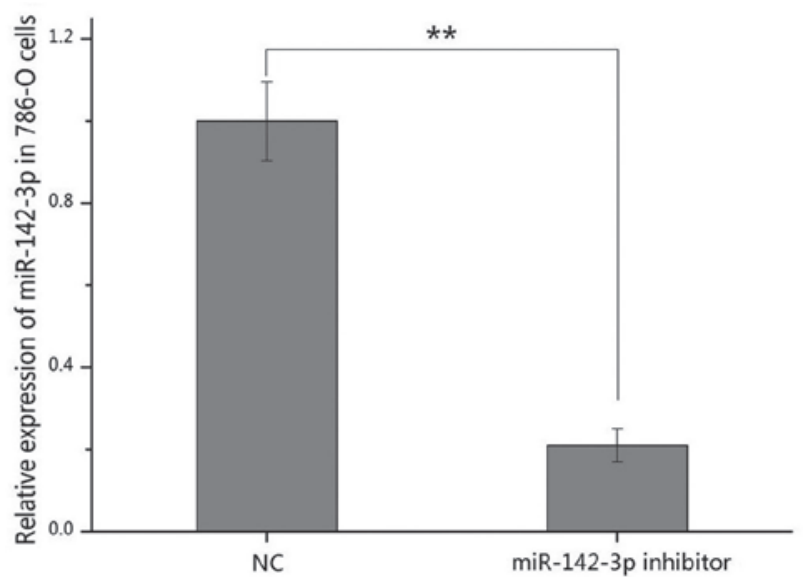

B

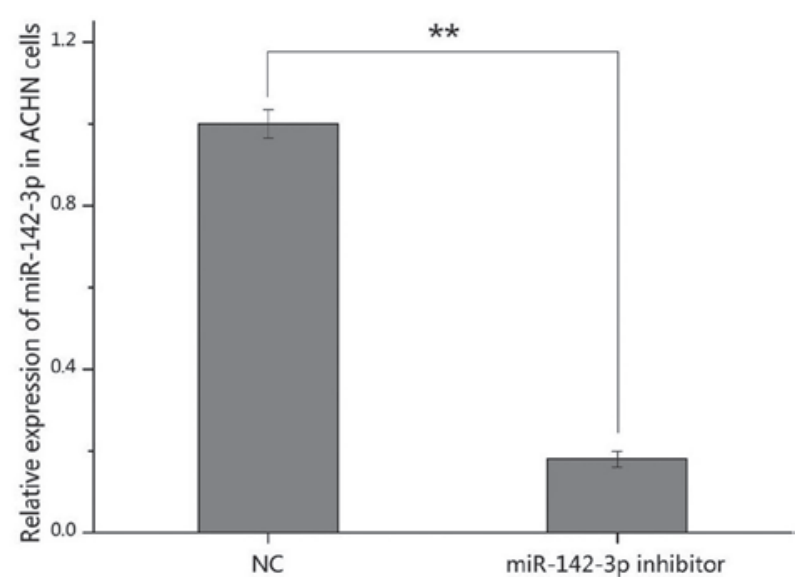

Figure 2. Validation of cell transfection efficiency. Relative expression of miR-142-3p in (A) 786-O and (B) ACHN cells transfected with either miR-142-3p inhibitor or a negative control. miR, microRNA; NC, negative control. ${ }^{* *} \mathrm{P}<0.01$.
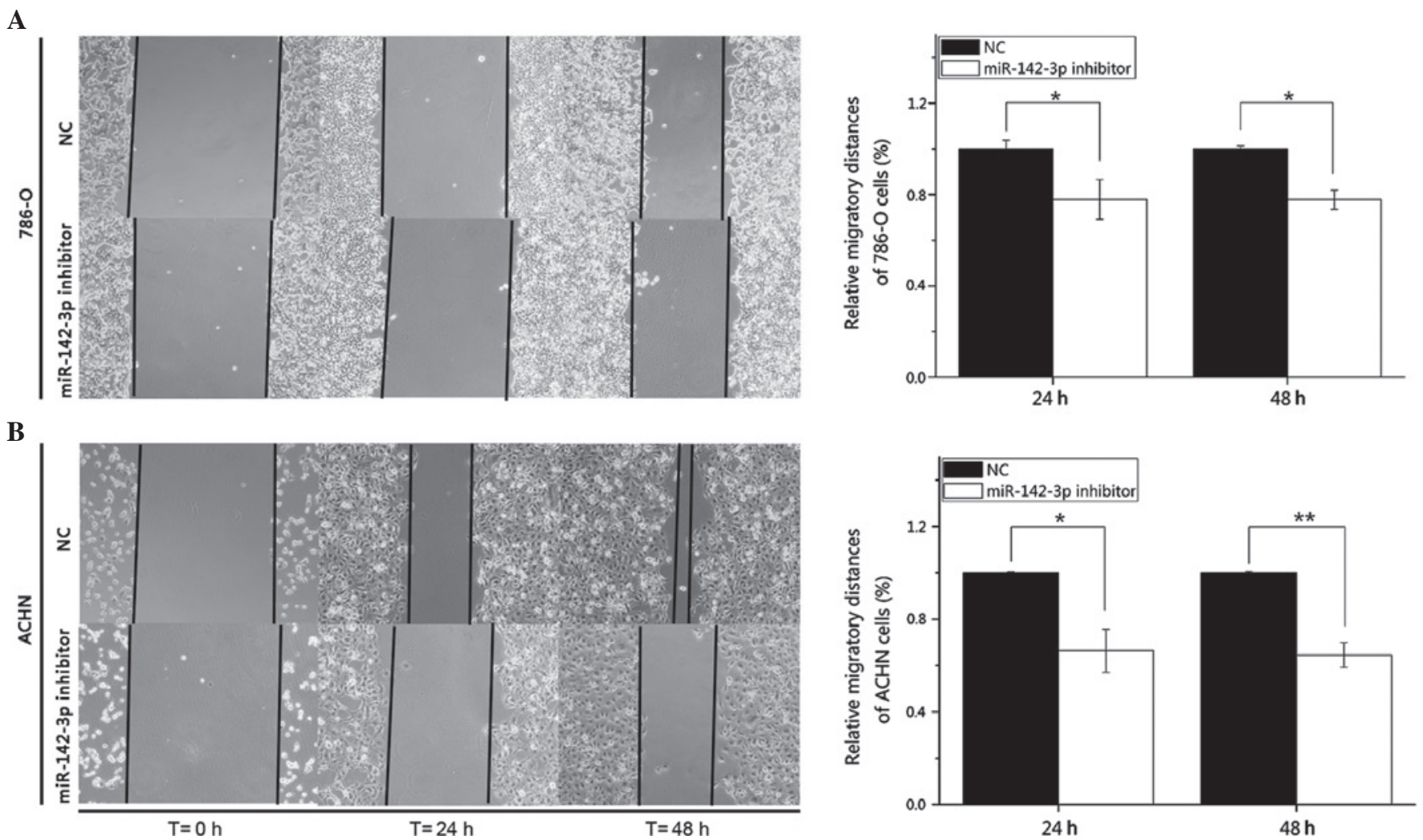

Figure 3. Wound healing assay. (A) Images of 786-O cells transfected with miR-142-3p inhibitor or negative control at $0 \mathrm{~h}, 24 \mathrm{~h}$ and $48 \mathrm{~h}$ after the scratches were made at the same point and statistical analysis of relative migratory distance at $24 \mathrm{~h}(\mathrm{P}<0.05)$ and $48 \mathrm{~h}(\mathrm{P}<0.05)$. (B) Images of the ACHN cells transfected with miR-142-3p inhibitor or negative control at $0 \mathrm{~h}, 24 \mathrm{~h}$ and $48 \mathrm{~h}$ after the scratches were made at the same point and statistical analysis of relative migratory distance at $24 \mathrm{~h}(\mathrm{P}<0.05)$ and $48 \mathrm{~h}(\mathrm{P}<0.01)$. miR, microRNA; NC, negative control. ${ }^{*} \mathrm{P}<0.05$ and ${ }^{* *} \mathrm{P}<0.01$.

present study demonstrated that the relative expression of miR-142-3p in the RCC tissues was significantly overexpressed when compared with the adjacent normal tissues $(\mathrm{P}<0.01)$, as presented in Fig. 1B. Such results indicated that miR-142-3p may act as an oncogene during RCC development. However, the function of miR-142-3p required further investigation.

Validation of cell transfection efficiency. The transfection efficiency of miR-142-3p inhibitor was quantified by qPCR, whilst comparisons were made with a negative control. The results indicated that miR-142-3p was downregulated by 79.04 and $82.02 \%$ compared with the negative control, following transfection in the $786-\mathrm{O}(\mathrm{P}<0.01$; Fig. $2 \mathrm{~A})$ and ACHN cells $(\mathrm{P}<0.01$; Fig. 2B), respectively.

miR-142-3p inhibitor suppresses 786-O and ACHN cell migration. Wound healing assays were performed to observe the function of miR-142-3p in cell migration. Images of each wound were captured at 0,24 , and 48 h post-transfection using a digital camera system (Fig. 3). The wounds of cells transfected with miR-142-3p inhibitor were wider than those of cells transfected with the negative control. Statistical 

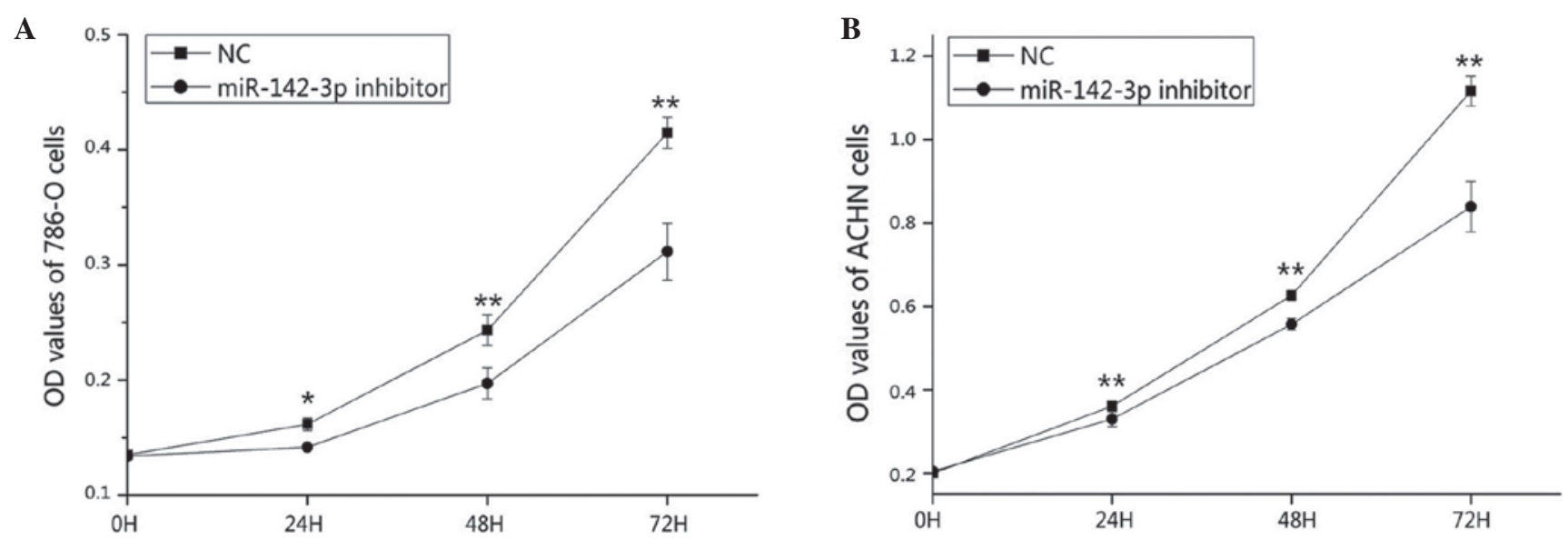

Figure 4. Cell proliferation of (A) 786-O and (B) ACHN measured by 3-(4,5-dimethylthiazol-2-yl)-2,5-diphenyltetrazolium bromide assay at different time intervals. miR, microRNA; NC, negative control; OD, optical density. ${ }^{*} \mathrm{P}<0.05$ and ${ }^{* *} \mathrm{P}<0.01$.

A

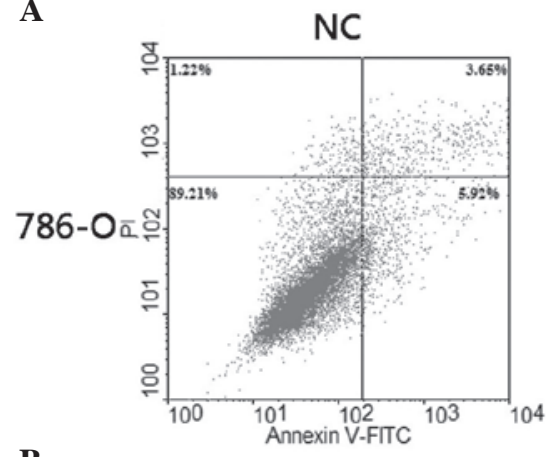

B

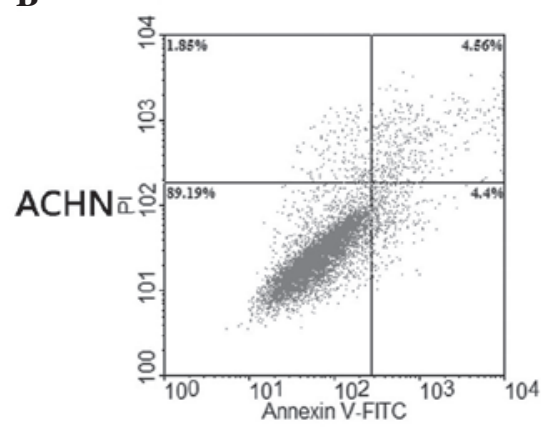

miR-142-3p inhibitor
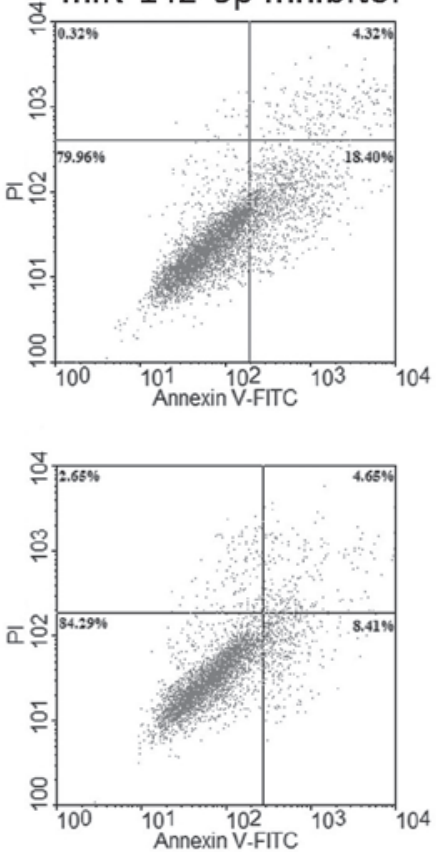
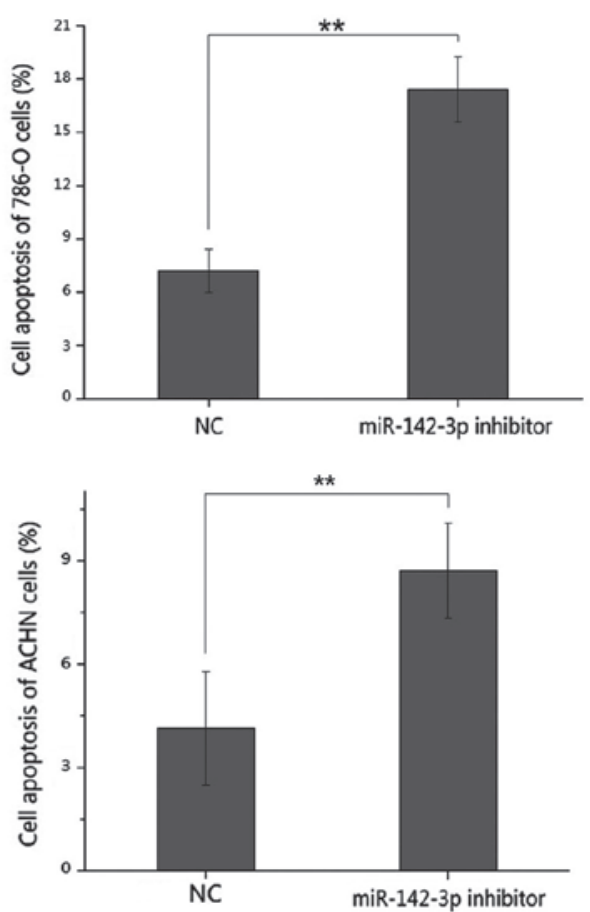

Figure 5. Cell apoptosis (\%) of (A) 786-O and (B) ACHN was measured by flow cytometry. miR, microRNA; NC, negative control; FITC, fluorescein isothiocyanate; PI, propidium iodide. ${ }^{* *} \mathrm{P}<0.01$.

analysis demonstrated that the migratory distances of the miR-142-3p inhibitor group were significantly decreased by $22.11 \%(\mathrm{P}<0.05)$ and $22.26 \%(\mathrm{P}<0.05)$ for the $786-\mathrm{O}$ cells, and by $33.66 \%(\mathrm{P}<0.05)$ and $35.47 \%(\mathrm{P}<0.01)$ for the ACHN cells at 24 and $48 \mathrm{~h}$ post-transfection, in comparison to the negative control group. Such results suggested that the downregulation of miR-142-3p inhibited the migratory ability of the RCC cells.

miR-142-3p inhibitor inhibits 786-O and ACHN cell proliferation. MTT assays were performed to determine if the downregulation of miR-142-3p had an impact on the proliferation of the RCC cells. The results demonstrated that the proliferation of the 786-O cells decreased by $10.15 \%$ $(\mathrm{P}<0.05), 19.04 \%(\mathrm{P}<0.01)$ and $24.84 \%(\mathrm{P}<0.01)$, and that the proliferation of the ACHN cells decreased by $8.59 \%(\mathrm{P}<0.01)$, $11.02 \%(\mathrm{P}<0.01)$ and $24.82 \%(\mathrm{P}<0.01)$, at 24,48 and $72 \mathrm{~h}$ post-transfection of the miR-142-3p inhibitor, as compared with the negative control. The results indicated that the inhibition of miR-142-3p expression significantly reduced the proliferation of the RCC cells (Fig. 4).

miR-142-3p inhibitor promotes 786-O and ACHN cell apoptosis. The effects of the miR-142-3p inhibitor on apoptosis were determined by flow cytometric analysis. The results demonstrated that the average early apoptosis rate of the 786-O cells, transfected with miR-142-3p inhibitor or negative control, was 17.40 vs. $7.20 \%(\mathrm{P}<0.01)$, whilst the average apoptotic rate of the ACHN cells was 8.71 vs. $4.14 \%(\mathrm{P}<0.01)$. 
This data indicated that the downregulation of miR-142-3p promoted RCC cell apoptosis (Fig. 5).

\section{Discussion}

The initiation and development of cancer involves the activation of a number of oncogenes and the dysfunction of numerous tumor suppressor genes. miRNAs have been identified to serve important roles in various types of cancer, regulating 50\% of human genes (5). Recent genomic studies of ccRCC have advanced our understanding of the molecular background and pathways, and the possible genetic alterations, implicated in ccRCC tumorigenesis (35). The most notable gene pathways involved in RCC tumorigenesis include the Von Hippel-Lindau (VHL)/hypoxia inducible factor (HIF), vascular endothelial growth factor (VEGF) and mechanistic target of rapamycin (mTOR) pathways. Therapies targeting these genes have been introduced into clinical practice. miRNAs target numerous genes, including HIF, mTOR, VEGF and VHL, through translational inhibition or the induction of mRNA degradation, which suggests that miRNAs function as important factors in RCC initiation and development $(36,37)$.

Previous studies have reported that miR-142-3p is dysregulated in various types of cancer (22-33), and may therefore function as a biomarker. The expression of miR-142-3p in RCC has not yet been validated by qPCR. However, recent microarray analyses comparing RCC and adjacent normal or benign kidney tissues demonstrated that miR-142-3p was significantly overexpressed in tumors when compared with paired control groups (18-21), suggesting that miR-142-3p may function as an oncogene in RCC development. Therefore, in the present study, qPCR was performed to quantify the relative expression of miR-142-3p in 53 paired RCC and adjacent normal tissues. Furthermore, the impacts of miR-142-3p on cellular migration, proliferation and apoptosis were analyzed through the use of wound healing, MTT and flow cytometry assays. The results demonstrated that miR-142-3p was significantly upregulated in RCC tissues in comparison to adjacent normal tissues. Downregulation of miR-142-3p, induced by the chemically synthesized miR-142-3p inhibitor, significantly suppressed cell migration and proliferation, and induced cell apoptosis in the 786-O and ACHN cells, suggesting that miR-142-3p may function as an oncogene during RCC tumorigenesis. However, the miR-142-3p-mediated molecular pathways that affect cell migration, proliferation and apoptosis remain unclear.

The various molecular mechanisms of miR-142-3p have been reported to affect tumor initiation, development, metastasis and invasion differentially, depending on the type of cancer that is present. This is believed to be due to the target genes involved being dependent on the type of cancer. In addition, different stages of cancer development exhibit the tissue- and temporal-specific manner of the function of miRNAs (8). For example, in breast cancer, overexpressed miR-142-3p regulates the properties of breast cancer stem cells (BCSCs), at least in part by activating the WNT signaling pathway and miR-150 expression. Previous in vivo experiments demonstrated that the enforced expression of miR-142 in normal mouse mammary stem cells resulted in the regeneration of hyperproliferative mammary glands, whilst the knockdown of endogenous miR-142 effectively suppressed organoid formation by BCSCs, and also slowed tumor growth initiated by human BCSCs (22). Downregulation of miR-142-3p in thyroid neoplastic tissues contributes to thyroid follicular tumorigenesis through the targeting of ASH1L and MLL1, and subsequently promotes its tumor suppressive function (23). In non-small cell lung cancer, overexpression of miR-142-3p represses transforming growth factor (TGF)-induced growth inhibition through the repression of TGF $\beta$ receptor 1 (26). However, a previous study investigating miR-142-3p in human acute lymphoblastic leukemia demonstrated that miR-142-3p inhibits cell proliferation by targeting the MLL-AF4 oncogene (27). miR-142-3p-mediated loss of protein tyrosine phosphatase non-receptor type 23 (PTPN23) expression may also be a key event in the pathogenesis of testicular germ cell tumors (30). By targeting the oncogenes cluster of differentiation 133, ATP-binding cassette, subfamily G, member 3 and leucine-rich repeat-containing $\mathrm{G}$ protein-coupled receptor 5 , miR-142-3p functions as a tumor suppressor in colon cancer cells (38). Other than its roles in tumorigenesis, miR-142 is also important for megakaryopoiesis, with the genetic ablation of miR-142 responsible for impaired megakaryocyte maturation, the inhibition of polyploidization, abnormal proplatelet formation and thrombocytopenia, through the orchestration of an actin cytoskeleton network (39).

In clinical application, the reduced expression of miR-142-3p in hepatocellular carcinoma and its overexpression in esophageal squamous cell carcinoma was significantly associated with reduced survival, suggesting that miR-142-3p may function as a prognostic predictor $(24,31)$. Serum miR-142-3p was identified to be associated with a high recurrence risk in patients with early-stage lung adenocarcinoma, and was a putative serum marker for risk assessment (40). The expression levels of miR-142-3p and miR-29a in peripheral blood mononuclear cells may be used as novel diagnostic markers with $\sim 90 \%$ sensitivity and $\sim 100 \%$ specificity for the diagnosis of acute myeloid leukemia (41). During human bronchial squamous carcinogenesis, miR-142-3p, which is typically upregulated during lung development, was first downregulated at the earliest stages of carcinogenesis, and was also subsequently upregulated during later stages, suggesting that the expression of miR-142-3p may be monitored to assess cancer development (42).

In conclusion, the present study demonstrated the expression and function of miR-142-3p in RCC tumorigenesis. The oncogenic function of miR-142-3p was indicated by its upregulated expression in RCC tissues, its inhibition of cellular migration and proliferation, and the reduction in cell apoptosis induced by an miR-142-3p inhibitor. Further investigation is required to analyze the miR-142-3p-mediated molecular pathway and its role in RCC development, with its potential to aid early disease detection and prognosis prediction, whilst serving as a therapeutic target, thus proving its clinical significance.

\section{Acknowledgements}

This study was supported by the National Natural Science Foundation of China (no. 81101922), the Science and Technology Development Fund Project of Shenzhen (nos. JCYJ20130402114702124 and JCYJ20130402113131201) and the Fund of Guangdong Key Medical Subject. 


\section{References}

1. Schaefer A, Stephan C, Busch J, Yousef GM and Jung K: Diagnostic, prognostic and therapeutic implications of microRNAs in urologic tumors. Nat Rev Urol 7: 286-297, 2010.

2. Garzon R, Calin GA and Croce CM: MicroRNAs in cancer. Annu Rev Med 60: 167-179, 2009.

3. Huntzinger E and Izaurralde E: Gene silencing by microRNAs: Contributions of translational repression and mRNA decay. Nat Rev Genet 12: 99-110, 2011.

4. Bartel DP: MicroRNAs: Target recognition and regulatory functions. Cell 136: 215-233, 2009.

5. Krol J, Loedige I and Filipowicz W: The widespread regulation of microRNA biogenesis, function and decay. Nat Rev Genet 11 597-610, 2010.

6. Carthew RW and Sontheimer EJ: Origins and mechanisms of miRNAs and siRNAs. Cell 136: 642-655, 2009.

7. Shenouda SK and Alahari SK: MicroRNA function in cancer: Oncogene or a tumor suppressor? Cancer Metastasis Rev 28: 369-378, 2009.

8. Guil S and Esteller M: DNA methylomes, histone codes and miRNAs: Tying it all together. Int J Biochem Cell Biol 41: 87-95, 2009.

9. Ridge CA, Pua BB and Madoff DC: Epidemiology and staging of renal cell carcinoma. Semin Intervent Radiol 31: 3-8, 2014.

10. Ferlay J, Shin HR, Bray F, Forman D, Mathers C and Parkin DM: Estimates of worldwide burden of cancer in 2008: GLOBOCAN 2008. Int J Cancer 127: 2893-2917, 2010.

11. Tavani A and La Vecchia C: Epidemiology of renal-cell carcinoma. J Nephrol 10: 93-106, 1997.

12. National Cancer Institute: Surveillance, Epidemiology, and End Results Program. SEER Stat Fact Sheets: Kidney and Renal Pelvis Cancer. http://seer.cancer.gov/statfacts/html/kidrp.html Accessed March 30, 2014.

13. Patel C, Ahmed A and Ellsworth P: Renal cell carcinoma: A reappraisal. Urol Nurs 32: 182-190, 2012.

14. Lam JS, Leppert JT, Figlin RA and Belldegrun AS: Role of molecular markers in the diagnosis and therapy of renal cell carcinoma. Urology 66 (Suppl): 1-9, 2005.

15. Rini BI, Campbell SC and Escudier B: Renal cell carcinoma. Lancet 373: 1119-1132, 2009.

16. Dias F, Teixeira AL, Santos JI, Gomes M, Nogueira A, Assis J and Medeiros R: Renal cell carcinoma development and miRNAs: A possible link to the EGFR pathway. Pharmacogenomics 14 1793-1803, 2013

17. Al-Ali BM, Ress AL, Gerger A and Pichler M: MicroRNAs in renal cell carcinoma: Implications for pathogenesis, diagnosis, prognosis and therapy. Anticancer Res 32: 3727-3732, 2012.

18. Liu H, Brannon AR, Reddy AR, Alexe G, Seiler MW, Arreola A, Oza JH, Yao M, Juan D, Liou LS, et al: Identifying mRNA targets of microRNA dysregulated in cancer: With application to clear cell renal cell carcinoma. BMC Syst Biol 4: 51, 2010.

19. Juan D, Alexe G, Antes T, Liu H, Madabhushi A, Delisi C, Ganesan S, Bhanot $\mathrm{G}$ and Liou LS: Identification of a microRNA panel for clear-cell kidney cancer. Urology 75: 835-841, 2010.

20. Yi Z, Fu Y, Zhao S, Zhang X and Ma C: Differential expression of miRNA patterns in renal cell carcinoma and nontumorous tissues. J Cancer Res Clin Oncol 136: 855-862, 2010.

21. Wu X, Weng L, Li X, Guo C, Pal SK, Jin JM, Li Y, Nelson RA, $\mathrm{Mu} \mathrm{B}$, Onami SH, et al: Identification of a 4-microRNA signature for clear cell renal cell carcinoma metastasis and prognosis. PLoS One 7: e35661, 2012.

22. Isobe T, Hisamori S, Hogan DJ, Zabala M, Hendrickson DG, Dalerba P, Cai S, Scheeren F, Kuo AH, Sikandar SS, et al: miR-142 regulates the tumorigenicity of human breast cancer stem cells through the canonical WNT signaling pathway. eLife 3: 01977, 2014

23. Colamaio M, Puca F, Ragozzino E, Gemei M, Decaussin-Petrucci M, Aiello C, Bastos AU, Federico A, Chiappetta G, Del Vecchio L, et al: miR-142-3p down-regulation contributes to thyroid follicular tumorigenesis by targeting ASH1L and MLL1. J Clin Endocrinol Metab 100: E59-E69, 2015.
24. Chai S, Tong M, Ng KY, Kwan PS, Chan YP, Fung TM, Lee TK, Wong N, Xie D, Yuan YF, et al: Regulatory role of miR-142-3p on the functional hepatic cancer stem cell marker CD133. Oncotarget 5: 5725-5735, 2014.

25. Han J, Yu J and Ling Z: Screening of specific miRNA in early gastric cancer. Zhonghua Wei Chang Wai Ke Za Zhi 17: 175-179, 2014 (In Chinese).

26. Lei Z, Xu G, Wang L, Yang H, Liu X, Zhao J and Zhang HT: MiR-142-3p represses TGF- $\beta$-induced growth inhibition through repression of TGF $\beta \mathrm{R} 1$ in non-small cell lung cancer. FASEB J 28 2696-2704, 2014

27. Dou L, Li J, Zheng D, Li Y, Gao X, Xu C, Gao L, Wang L and Yu L: MicroRNA-142-3p inhibits cell proliferation in human acute lymphoblastic leukemia by targeting the MLL-AF4 oncogene. Mol Biol Rep 40: 6811-6819, 2013

28. Lv M, Zhang X, Jia H, Li D, Zhang B, Zhang H, Hong M, Jiang T, Jiang Q, Lu J, et al: An oncogenic role of miR-142-3p in human T-cell acute lymphoblastic leukemia (T-ALL) by targeting glucocorticoid receptor- $\alpha$ and cAMP/PKA pathways. Leukemia 26: 769-777, 2012.

29. Kanaan Z, Roberts H, Eichenberger MR, Billeter A, Ocheretner G, Pan J, Rai SN, Jorden J, Williford A and Galandiuk S: A plasma microRNA panel for detection of colorectal adenomas: A step toward more precise screening for colorectal cancer. Ann Surg 258: 400-408, 2013.

30. Tanaka K, Kondo K, Kitajima K, Muraoka M, Nozawa A and Hara T: Tumor-suppressive function of protein-tyrosine phosphatase non-receptor type 23 in testicular germ cell tumors is lost upon overexpression of miR142-3p microRNA. J Biol Chem 288 23990-23999, 2013.

31. Lin RJ, Xiao DW, Liao LD, Chen T, Xie ZF, Huang WZ, Wang WS, Jiang TF, Wu BL, Li EM and Xu LY: miR-142-3p as a potential prognostic biomarker for esophageal squamous cell carcinoma. J Surg Oncol 105: 175-182, 2012.

32. Hui AB, Lenarduzzi M, Krushel T, Waldron L, Pintilie M, Shi W, Perez-Ordonez B, Jurisica I, O'Sullivan B, Waldron J, et al: Comprehensive microRNA profiling for head and neck squamous cell carcinomas. Clin Cancer Res 16: 1129-1139, 2010.

33. Namløs HM, Meza-Zepeda LA, Barøy T, Østensen IH, Kresse SH, Kuijjer ML, Serra M, Bürger H, Cleton-Jansen AM and Myklebost O: Modulation of the osteosarcoma expression phenotype by microRNAs. PLoS One 7: e48086, 2012.

34. Edge SB,Byrd DR, Compton CC, etal: AJCC Cancer Staging Manual. 7th edition. Springer Verlag, New York, NY, USA, pp547-560, 2009.

35. Rydzanicz M, Wrzesiński T, Bluyssen HA and Wesoły J: Genomics and epigenomics of clear cell renal cell carcinoma: Recent developments and potential applications. Cancer Lett 341: 111-126, 2013.

36. Maher ER: Genomics and epigenomics of renal cell carcinoma. Semin Cancer Biol 23: 10-17, 2013

37. Chow TF, Mankaruos M, Scorilas A, Youssef Y, Girgis A, Mossad S, Metias S, Rofael Y, Honey RJ, Stewart R, et al: The miR-17-92 cluster is over expressed in and has an oncogenic effect on renal cell carcinoma. J Urol 183: 743-751, 2010.

38. Shen WW, Zeng Z, Zhu WX and Fu GH: miR-142-3p functions as a tumor suppressor by targeting CD133, ABCG2, and Lgr5 in colon cancer cells. J Mol Med (Berl) 91: 989-1000, 2013.

39. Chapnik E, Rivkin N, Mildner A, Beck G, Pasvolsky R, Metzl-Raz E, Birger Y, Amir G, Tirosh I, Porat Z, et al: miR-142 orchestrates a network of actin cytoskeleton regulators during megakaryopoiesis. eLife 3: e01964, 2014.

40. Kaduthanam S, Gade S, Meister M, Brase JC, Johannes M, Dienemann H, Warth A, Schnabel PA, Herth FJ, Sültmann H, et al: Serum miR-142-3p is associated with early relapse in operable lung adenocarcinoma patients. Lung Cancer 80: 223-227, 2013.

41. Wang F, Wang XS, Yang GH, Zhai PF, Xiao Z, Xia LY, Chen LR, Wang Y, Wang XZ, Bi LX, et al: miR-29a and miR-142-3p downregulation and diagnostic implication in human acute myeloid leukemia. Mol Biol Rep 39: 2713-2722, 2012

42. Mascaux C, Laes JF, Anthoine G, Haller A, Ninane V, Burny A and Sculier JP: Evolution of microRNA expression during human bronchial squamous carcinogenesis. Eur Respir J 33: 352-359, 2009. 